Audiofonologii, Sekcji Logopedycznej Towarzystwa Kultury Języka.

Konferencjom i wydawnictwom poświęcony jest (jak sądzę nieco sztucznie wyodrębniony) rozdział 10 .

W rozdziale 11 znajdujemy zarys współczesnego systemu opieki logopedycznej w Polsce, a przedmiotem rozważań Autorki w rozdziale 12 są konkursy recytatorskie i ich miejsce w krzewieniu kultury żywego słowa.

W uwagach konicowych E.M. Minczakiewicz kreśli kilka propozycji godnych uwzględnienia przy tworzeniu nowego systemu kształcenia logopedów i zdobywania przez nich specjalizacji.

Istotną objętościowo częścią pracy (około 70 stron) jest 7 aneksów. Zawierają one głównie przepisy dotyczące zawodu logopedy (np. Zarządzenie Ministra Edukacji Narodowej z dn. 11.12.1989 r. w sprawie warunków, zasad, trybu uzyskiwania stopni specjalizacji zawodowej) i sytuacji dziecka szkolnego $\mathrm{z}$ zaburzeniami rozwojowymi (Zarządzenie Ministra Edukacji Narodowej z dn. 25.05.1993r. w sprawie zasad udzielania pomocy psychologicznej i pedagogicznej).
Zdziwienie budzi treść aneksu 7 - kilka uwag na temat diagnozy logopedycznej. Zagadnienie to $w$ żaden sposób nie koresponduje z zawartością całej książki.

Uważny czytelnik omawianej pracy bẹzie żałował, że nie znajdzie w niej erraty. Pomijając sprawę „literówek", które najwyżej irytuja, znajdujemy w książce zaniedbania korektorskie wprowadzajace do tekstu zakłamania (np. w tytule książki J. Nowak występuje termin „słuch fonetyczny", gdy tymczasem powinien się tam znaleźć „słuch fonematyczny”; tytuł pracy L. Gapika brzmi Hipnoza i hipnoterapia, a nie Hipnoza $i$ hipoterapia).

Wielką zaletą pracy E.M. Minczakiewicz jest wykorzystanie bogatej literatury przedmiotu i dlatego bibliografia zestawiona przez Autorkę może stanowić cenne źródło informacji dla czytelników zainteresowanych studiowaniem zagadnień związanych $\mathrm{z}$ historią polskiej logopedii.

\section{Ewa Kuczyńska}

1 S. Grabias, Logopedyczna klasyfikacja zaburzent mowy. "Audiofonologia", Tom VI, 1994, s. 8.

\title{
Profesor Bogdan Suchodolski. Jego filozofia, myśl pedagogiczna i dzialalność, Warszawa 1996, ss. 168
}

W dniu 2 października 1992 roku zmarł Profesor Bogdan Suchodolski, jeden z najwybitniejszych polskich humanistów. Zarząd Glówny Polskiego Towarzystwa Pedagogicznego, którego B. Suchodolski był współtwórca, postanowił uczcić pamięć Profesora organizując sesję naukową poświęconą jego działalności i twórczości naukowej. W skład Komitetu programowego tegoż spotkania naukowego weszli: Zbigniew Kwieciński - przewodniczący Polskiego Towarzystwa Pedagogicznego, Henryka Kwiatkowska - wiceprzewodnicząca PTP i wieloletnia wspólpracowniczka Profesora, Irena Wojnar, czlonek ZG PTP.

Publikacja pod wymienionym tytułem jest zbiorem zamówionych wcześniej referatów i wypowiedzi uczestników - gości, biorących udział w sesji, która odbyła się 15 grudnia 1994 roku w Pałacu Staszica w Warszawie, gromadząc najbliższych współpracowników Uczonego, kolegów i uczniów.

Książka skłađa się ze: wstępu, zawierającego "Slowo na otwarcie konferencji" Z. Kwiecińskiego oraz dwóch części zatytułowanych: Swiat myśli filozoficzno-pedagogicznej - wielość ujeć i Refleksja pedagogiczna - implikacje praktyczne. Dopełnieniem refleksji teoretycznej jest kalendarium życia i wykaz publikacji B. Suchodolskiego w opracowaniu I. Wojnar.

W części poświęconej myśli filozoficzno-pedagogicznej autorzy artykułów (S. Wołoszyn, I. Wojnar, W. Okoń, J. Szczepański, 
Cz. Kupisiewicz, W. Markiewicz), analizując bogatą twórczość $\mathrm{B}$. Suchodolskiego z zakresu historii filozofii, historii kultury i pedagogiki, ukazali główne idee jego refleksji naukowej.

S. Wołoszyn celem swoich rozważań uczynił zagadnienie Przebudowy podstaw humanistyki i udzialu w niej Bogdana Suchodolskiego. „W twórczości naukowej Bogdana Suchodolskiego szczególne miejsce zyskały metodologiczne i merytoryczne rozważania nad istotą i rozumieniem świata humanistycznego, pisze S. Wołoszyn, co sprowadzało się przede wszystkim do zrozumienia istoty i historycznego rozwoju kultury oraz do dociekania istoty i przejawów w różnych odmianach $\mathrm{i}$ typach kultury jej ducha, czyli świadomości człowieka i ludzkich zbiorowości" (s. 10-11). Zdaniem autora artykułu B. Suchodolski poszerzyl świat humanistycznego poznania i humanistycznego myślenia. Wpisując polskiego Uczonego na liste nie tylko polskich, ale i europejskich najwybitniejszych uczonych, przedstawicieli humanistycznego poznania, naznaczając jemu miejsce w tym nurcie przywołał jego słowa: „W jakqkolwiek stronę skierujemy naszą uwage zobaczymy zawsze świat humanistyczny jako jedyną i prawdziwą ojczyznę człowieka" (s. 14).

Humanizm - mimo wszystko to niezwykle interesująca wypowiedź I. Wojnar, w której widoczna jest nie tylko znakomita znajomość twórczości i działalności B. Suchodolskiego, ale ujawnia się także osobisty stosunek autorki do Uczonego. Uświadomiła bowiem polskiemu czytelnikowi złożoność wielu sytuacji, w której przyszło żyć i tworzyć B. Suchodolskiemu. Jednak w swojej twórczości i działalności bronił nade wszystko wartości humanistycznych, podkreślała autorka, ujawniając je w podwójnej perspektywie: historycznej i światopoglądowej. W jego dorobku studia nad myślą pedagogiczną uzupełniają się studiami nad kulturą i filozofią człowieka. Stąd taki, a nie inny dobór myślicieli w poglądach, których poszukiwał ponadczasowych wartości. Takich wartości, które są niezbędne w chwilach trudnych, aby nie zatracić wiary w człowieka, aby mieć „racjonalną nadzieję", która pozostała temu polskiemu Uczonemu. Dlatego słowa ,mimo wszystko" nabierają szczególnego wymiaru w relacji $\mathrm{z}$ humanizmem, pozostając uzupełnieniem, co więcej warunkiem koniecznym zaistnienia świata wartości humanistycznych. Jest to także wyraz oraz najwyższe świadectwo optymizmu B. Suchodolskiego, wiary w sens i istotę człowieka. Końcowe zdania I. Wojnar są zaproszeniem do zadumy i refleksji nad dziełem życia B. Suchodolskiego. „Analiza myśli Profesora, pisze, ujawnia nadzieje i rozczarowania, a może tylko złudzenia? Tych wszystkich, którzy za pomocą edukacji chcieliby zmienić świat, a jednocześnie zachẹca do sięgania w głab doświadczeń i napięć ludzkiej istoty w ten świat uwikłanej, rozdartej między los i decyzje, ograniczenia i możliwości" (s. 31).

Wychowanie a strategie życia to jedna z prac omawianego humanisty, którą W. Okoń uważa za jedną z najcenniejszych książek $w$ dorobku Uczonego, której główne idee wykorzystał dla zilustrowania relacji miedzy wychowaniem a życiem w artykule Bogdan Suchodolski o wychowaniu $i$ strategii życia. Zwiqzek wychowania z życiem?. Już samo takie ustawienie sprawy stało się, wg W. Okonia, podstawą przewartościowania celów i zadań pedagogiki. A treści owej koncepcji spetniały rolę inspirującą w przemianach oświatowych.

$\mathrm{Z}$ rozważaniami na temat strategii życia łączy się refleksja B. Suchodolskiego określona mianem "kształtu życia", której istote przypomnial J. Szczepański (O Bogdana Suchodolskiego koncepcji ksztaltu życia). Podkreślił on, iż wizja „kształt życia” nie jest modelem osobowości ani też poglądem na życie, ale koncepcjq filozofii życia, wyrosłą z potrzeb społecznych, ekonomicznych i kulturalnych, uwzględniającą indywidualizm jednostki. Jednostki, która może tworzyć ksztalt swojego życia, na który składa się każdy dzień, tak, jak zapis każdego dnia składa się na dziennik.

Wszystkie, nazwijmy, cząstkowe koncepcje pedagogiczne B. Suchodolskiego miały na celu wychowanie człowieka do przyszłości. Ten element twórczości omówił Cz. Kupisiewicz (Bogdana Suchodolskiego koncepcja wychowania dla przyszlości - od wychowania dla nowego jutra do wychowania mimo wszystko), stwierdzając, iż było to nowe myślenie o szkole, wskazujące na potrzebe reform edukacyjnych. Propozycje B. Suchodolskiego przedstawił na tle innych, późniejszych koncepcji wychowania 
dla przyszłości, które implikowały potrzebe reform oświatowych, wskazywały im kierunek.

Część pierwszą książki zamyka artykuł W. Markiewicza na temat: Obecność Bogdana Suchodolskiego w polskim życiu naukowym, w którym zostały przedstawione jego inicjatywy mające na celu rozwój polskiej nauki w ogólności, a w szczególności formowanie i promowanie tych jej gałęzi, które były niedoceniane. Wprowadzal polską naukę na forum światowe, będąc organizatorem, współorganizatorem, przewodniczącym wielu towarzystw $\mathrm{i}$ organizacji naukowych zarówno polskich, jak i europejskich. Rozległość zainteresowań i działalności naukowej skłoniły autora tego artykułu do następującego stwierdzenia: „Bogdana Suchodolskiego nazwać by można Nienasyconym Intelektem" (s. 58).

W II części recenzowanej książki autorzy artykułów wykorzystując niektóre idee $\mathrm{z}$ dorobku B. Suchodolskiego wskazywali na ich odniesienia, czy też następstwa $w$ praktyce życia codziennego, a więc w nauce, kulturze, edukacji i życiu społecznym. W szczególności omówiono zagadnienia szeroko rozumianej kultury z jej różnymi przejawami i odniesieniami do wychowania i funkcjonowania człowieka w życiu społecznym.

S. Ruciński odwołał się w swoim artykule do refleksji B. Suchodolskiego o ideach wychowania moralnego (Wychowanie moralne w ujeciu Bogdana Suchodolskiego), która zawierała $w$ sobie elementy aksjologiczne $z$ przeszlości kultury, jak i odwoływała się do rzeczywistości polskiej, w której żył i działał omawiany uczony. Nazwał B. Suchodolskiego człowiekiem, który pragnął ratować polską szkołę. $\mathrm{Z}$ kolei problematyka kultury będąca rezultatem wychowania i kształcenia przez naukę to rozważania J. Kubina (Kultura umyslowa - model i rezultat ksztalcenia ogólnego przez nauke). W pewnym sensie kontynuowali ją B. Chmielowski (Bogdana Suchodolskiego pedagogika kultury) oraz D. Jankowski pisząc na temat: Bogdan Suchodolski o upowszechnieniu $i$ uspolecznieniu kultury. $\mathrm{O}$ wartościach, którym był wierny B. Suchodolski znajdziemy w artykułach: A. Sztylki Czlowiek wierny ideom humanizmu oraz W. Kamińskiego Slużba Ojczyźnie w systemie wartości Profesora Bogdana Suchodol- skiego. $\mathrm{Na}$ inne wątki twórczości B. Suchodolskiego, nie zawsze definiowane, wskazali w swoich artykułach W. Pielasinska (Ekspresja $i$ wspólnota w ujeciu Profesora Bogdana Suchodolskiego) oraz J. Górniewicz (Profesora Bogdana Suchodolskiego koncepcja wyobraźni spolecznej). Dopełnieniem różnorodnych zagadnień przedstawionych w recenzowanym opracowaniu jest omówienie twórczości historyczno-oświatowej, co uczynili J. Hellwig (Profesor Bogdan Suchodolski jako historyk wychowania) oraz T. Gumula i S. Majewski (Dzieje oswiaty $i$ wychowania oraz problematyka reform wspotczesnych systemów edukacyjnych). $\mathrm{Z}$ kolei E. Rodziewicz, ukazując inność prac B. Suchodolskiego (Powroty, refleksje, autorefleksje, pytania) podkreślala, iż uczony może pełnić określone funkcje, nie tylko $w$ życiu, ale i poprzez swoje prace. $Z$ bogatą twórczością $B$. Suchodolskiego łączyła się działalność w różnorodnych instytucjach, towarzystwach $\mathrm{i}$ organizacjach naukowych i kulturalno-oświatowych. Jeden z wycinków tej działalności omówił J. Gajda w artykule Dzialalnosć Bogdana Suchodolskiego w Narodowej Radzie Kultury.

$\mathrm{Na}$ osobną uwage zasługuja te artykuły, które ukazują inną sferę dzieła i wielkości B. Suchodolskiego, nie zawsze zresztą dostatecznie ujętą w jego twórczości i działalności. Mowa tutaj o jego mistrzostwie. Portret mistrza, na przykładzie osoby B. Suchodolskiego, nakreślili R. Lukaszewicz (Pejzaż z Ikarem), A. Ratuś (Nauczyciel nauczycieli) i A. Góralski (Pamieci Profesora Bogdana Suchodolskiego).

Przedstawiony w recenzowanej publikacji „los" B. Suchodolskiego, jest znaczącym fragmentem losów inteligencji polskiej uwikłanej w meandry historii, polityki i polski ład i nieład społeczny. Przecież intelektualna biografía Uczonego obfituje w różnorodne przejawy rozwoju kultury i nauki polskiej z jej osiągnięciami, konfliktami, zagrożeniami i poniesionymi klęskami. Dlatego, jak wykazali autorzy omawianej publikacji, czego możemy także doświadczyć czytając prace B. Suchodolskiego, w jego twórczości mamy do czynienia $\mathrm{z}$ wielością ujęć omawianych problemów. W tej wielości i różnorodności działań i myślenia Uczonego jawi się także portret człowieka troszczącego się o losy własnej Ojczyzny na różnych płasz- 
czyznach. Umiejącego (czy też próbującego) właściwie oceniać i cenić, wskazującego na dobro i zło. Zaś myślenie o wychowaniu prowadził w różnych kierunkach, wprowadzając różnorodne kategorie filozoficzno-pedagogiczne i antropologiczne, spięte klamrą humanizmu i mimo wszystko wiary w człowieczeństwo. Jak nikt w Polsce stworzył wspaniałe „kreacje” wychowania warte ciaglego przypominania, a były to: wychowanie dla świata człowieka, wychowanie dla różnych strategii życia, wychowanie na miarę naszych czasów, wychowanie jako naprawa ludzkiego świata, czyli wychowanie mimo wszystko. Widząc zagrożenia człowieka, mówiąc o wychowaniu na rozdrożu, tworzył jednak pedagogikę nadziei, która wynikała $\mathrm{z}$ jego wiary, iż społeczeństwo, może być społeczeństwem wychowującym. Idee te odnosił zwłaszcza do społeczeństwa polskiego, gdyż pragnął zmienić norwidowską diagnozę o nas, brzmiącq dialektycznie, iż ,jesteśmy wielkim narodem i żadnym społeczeństwem".

W recenzowanej książce nieodparcie pojawia się motyw o mistrzostwie i wielkości Uczonego. Bowiem, dwojakie jest znaczenie B. Suchodolskiego w dziejach nauki i kultury polskiej, a nawet powszechnej. Pierwsze naznaczaja jego dzieła naukowe, w których zawarte idee zmuszają czytelników do refleksji, drugi wy- miar to świadectwa osób, które miały szczęście spotkać Uczonego na swej drodze.

Wśród, jak się wydaje, niewielu publikacji poświęconych osobie B. Suchodolskiego, ta wydaje się być znaczącą $\mathrm{z}$ wielu powodów. Naszkicowany tutaj zostal naukowy i po części psychologiczny wizerunek wielkiego humanisty, proponującego nam wiele ponadczasowych wartości i dróg rozwiq̨zywania problemów egzystencjalnych. Ponadto mamy tutaj do czynienia $\mathrm{z}$ wysokimi walorami intelektualnymi tekstów. Niemniej jednak, uważny czytelnik po zapoznaniu się z treścią książki, poczuje pewien „niedosyt", który można wyrazić stwierdzeniem „za mało wypowiedziano wobec dokonań tego Uczonego". Lecz nie jest to zarzut poczyniony autorom, gdyż jest rzeczą oczywistą, iż na jednej konferencji, czy w jednej publikacji nie można zamknąć ogromnego dzieła (idei i materialnych efektów) życia B. Suchodolskiego. Dlatego praca zasługuje na upowszechnienie w szerokich kręgach czytelników. Dla tych, którzy nie mogą? lub nie chcą więcej wiedzieć o B. Suchodolskim (nie pytajmy o powody!) niech będzie ona wystarczającą. Zaś dla tych, którzy poszukują ,mądrzejszego wymiaru życia" niech będzie zachętą do dalszego zagłębiania się w refleksji B. Suchodolskiego.

Wadyslawa Szulakiewicz

\section{Rola i miejsce kobiet w edukacji i kulturze polskiej, pod red. Wieslawa Jamroźka i Doroty Żolądź-Strzelczyk, t. 1, Instytut Historii UAM, Poznań 1998, s. 215}

W tradycyjnej historiografii problematyka kobieca obecna była w stosunkowo skromnym zakresie. Dopiero w ostatnich dziesięcioleciach naszego stulecia postmodernizm wskazał na nowe, bądź zaniedbane wcześniej problemy, w których wielu historyków ujrzało nowe możliwe do podjęcia tematy badawcze. Wśród podejmowanych coraz chętniej tematów znalazły się te, które pośrednio lub bezpośrednio wskazywały na aktywną rolę kobiet $w$ historii. W rezultacie zaczęły się ukazywać liczne pozy- cje książkowe poświęcone tej kwestii. Punktem kulminacyjnym w historiografii zachodniej, na polu badań dotyczących kwestii kobiecej, było wydanie, na początku lat dziewięćdziesiątych, monumentalnej pieciotomowej l'Historie des femmes en Occident (Historia kobiet na Zachodzie, Plon, 1991 -1992), pod redakcją Michelle Perrot i Georgesa Duby oraz książki M. Perrot pod wiele mówiącym tytułem Les Femmes les silences de l'historie (Kobiety, czyli milczenie historii, Flammarion, 1998). 